\title{
Practical Family Medicine: After-Hours Video Telehealth, Office Procedures, Polyp Follow-up in Older Patients, Terminology for Domestic Violence Intervention
}

\author{
Marjorie A. Bowman, MD, MPA, Dean A. Seebusen, MD, MPH, and \\ Anne Victoria Neale, $\mathrm{PhD}, \mathrm{MPH}$
}

This issue primarily contains practice-based research reports. For a commentary on these articles, see Tapp. ${ }^{1}$ JABFM also has a call for submissions and accepted pre-print articles specifically on COVID at our Web site, www.jabfm.org. These online COVID-related articles will be collated into a future print issue. This issue also has additional articles, encompassing a range of issues, as is common for JABFM. (J Am Board Fam Med 2020;33:641-642.)

As American medicine is taking a crash course in telemedicine, Sankaran et $\mathrm{al}^{2}$ investigate the willingness and desire of patients to use video for afterhours calls. The pandemic, along with the increased use of video cell phones, has increased telehealth, including video telehealth, much of which, to date, has been during the day, not after hours. Some telehealth video connections require the patient to accept an invite from the physician. The study had expected findings, such as older individuals are not as comfortable with video. However, more surprising was patient beliefs regarding which type of visits would work best for telehealth. For example, some physicians might think it would be particularly helpful to have visual contact for mental health or personal concerns, but this was concerning to a significant minority of the patients. I (MAB) was pleased that some patients recognized that the lack of an in-person visit could lead to incorrect diagnosis. Other interesting patient beliefs are found in the article.

Almost $50 \%$ of family physicians are women. The data reported by Wilkinson et $\mathrm{al}^{3}$ about family physicians taking the recertification examination is consistent with this US trend. The number of hours worked is most similar between male and female physicians about age 50 to 60 years, which seems consistent with issues related to childbearing for

Conflict of interest: The authors are editors of the $7 A B F M$. women (younger age group) and retirement among dual-professional (older age-group) couples.

Irvine $^{4}$ presents a case and review of HMCG antibody-induced muscle disorders with statins, describing some of the variability in timing and severity. We also suggest reading Candib's ${ }^{5}$ vivid portrayal of "asylum" torture.

Family physicians and their older patients must make decisions on the need for ongoing colonoscopies after prior polyps. Lack of clear guidance, and lack of clarity by polyp type(s), increase the complexities. Family physicians tend to take 1 of 3 different decision paths, according to Schoenborn et al. ${ }^{6}$

This issue also includes 1 clinical review, which provides practical tips on office interventions for common ambulatory diagnoses or injuries, thus potentially avoiding unnecessary surgical referral. ${ }^{7}$

Domestic violence happens commonly, is often a learned behavior, and can be difficult to unlearn. Authors Tu and Penti ${ }^{8}$ provide some helpful, practical recommendations for addressing the person perpetrating abuse in ways that could assist in behavior change.

Call for articles: $7 A B F M$ is currently soliciting articles related to Veterans Health: https://www. jabfm.org/sites/default/files/CALL\%20FOR\%20 PAPERS_VeteransHealth.pdf; with a submission deadline of September 11, 2020. We are also seeking articles related to COVID-19: https:// www.jabfm.org/sites/default/files/COVID19.pdf. In addition, note that accepted articles (preprint) are quickly posted on the $7 A B F M$ Web site: 
https://www.jabfm.org/content/covid-19-aheadprint-subject-collection. These online Covid-19 topic articles will be collated into a future print issue.

To see this article online, please go to: http://jabfm.org/content/ 33/5/641.full.

\section{References}

1. Tapp H. The changing face of primary care research and practice-based research networks (PBRNs) in the light of the COVID-19 pandemic. J Am Board Fam Med 2020;33:645-649.

2. Sankaran J, Menachery SM, Bradshaw RD. Patient interest in video integration for after-hours telemedicine. J Am Board Fam Med 2020;33:765-773.

3. Wilkinson E, Coffman M, Petterson S, Jabbarpour Y. Gender differences in reported weekly work hours among family physicians. J Am Board Fam Med 2020;33:653-654.

4. Irvine N. Anti-HMGCR myopathy: a rare and serious side effect of statins. J Am Board Fam Med 2020;33:785-788.

5. Candib LM. Asylum body work. J Am Board Fam Med 2020;33:815.

6. Schoenborn NL, Boyd CM, Massare J, Park R, Choi Y, Pollack CE. Primary care clinician decision-making around surveillance colonoscopies in older adults with prior adenomas. J Am Board Fam Med 2020;33:796798.

7. Akiki RK, Raman Mehrzad R. Practical management of common skin injuries, lacerations, wounds, trigger fingers, and burns. J Am Board Fam Med 2020;33:799_ 808.

8. Penti B, Timmons J, Adams D. How we talk about "perpetration of intimate partner violence" matters. J Am Board Fam Med 2018;31:635-44. 